\title{
CHANGES IN THE INTRA-ARTICULAR TEMPERATURE OF THE KNEE WITH CUTANEOUS VASOCONSTRICTION AND VASODILATATION OF THE TOES IN NORMAL SUBJECTS*
}

\author{
BY \\ RAYMOND PENNEYS AND NATHAN M. SMUKLER \\ From the Vascular Section of the Robinette Foundation and the Arthritis Section, Department of Medicine, \\ Hospital of the University of Pennsylvania
}

(RECEIVED FOR PUBLICATION JULY 10, 1956)

Hollander and Horvath (1949) and Horvath and Hollander (1949) have reported two sets of experiments in which they studied the changes induced in the intra-articular temperature by the application of cold, or heat, to another part of the body. In the first series of experiments, the application of cold packs to one knee caused an increase in the temperature of the other knee joint, and hot packs to one knee caused a decrease in the temperature of the other knee joint. In the second series of experiments, the immersion of one leg in water at $103^{\circ} \mathrm{F}$. did not alter the temperature of the ankle joint of the opposite leg even though it produced cutaneous vasodilatation of the toes of the unimmersed foot.

Stimulated by their work, we became interested in measuring the effect of cold and heat, somewhat differently applied, upon joint temperature. Body cooling has been known for many years to elicit marked cutaneous vasoconstriction in the extremities, just as body warming has been known to elicit marked cutaneous vasodilatation in the extremities. For certain physiological and clinical considerations to be discussed later, we are describing in this paper the changes in joint temperature which accompany these conspicuous changes in skin blood flow.

\section{Method}

The seven subjects studied were healthy young adults, 20 to 35 years of age (average 27). Skin surface temperatures were measured by thermocouples attached by one layer of adhesive tape to the skin on the dorsal surface

* This work was supported in part by a grant (G-51-30) from the Life Insurance Medical Research Fund, and a grant from the Helen Augusta Parkhill Memorial Fund. of the toes of both feet, and to the skin of the anterior surface of each knee. The knee joint was chosen for measurement of the intra-articular temperature because its size facilitates the insertion of the thermocouple within the joint space. Intra-articular temperatures were obtained by the technique of Horvath and Hollander (1949); using a medial approach, a 19 needle, bored to an 18 internal diameter, was inserted into the joint space. A fine copper-constantan thermocouple was threaded through the needle for a distance greater than the length of the needle, to insure the projection of its tip into the joint space. The needle and all thermocouples were left in situ throughout the entire experiment. The intra-articular temperature was measured in only one extremity, while the skin temperatures were taken in both extremities in order to determine whether the presence of the needle, and thermocouple, within the joint space in some manner influenced the skin temperature of that extremity. No difference between the skin temperatures of the two extremities was found. The skin and intra-articular temperatures were recorded every 2 minutes by a Brown potentiometer. Oral temperatures were also obtained, from time to time, with a standard clinical mercury thermometer.

Observations were made first during a state of cutaneous vasoconstriction of the toes, and then during a state of cutaneous vasodilatation. Cutaneous vasoconstriction was induced by exposure of the fasting subject, clad only in a light cotton dressing-gown and underwear shorts, to cool air in a thermoregulated, constant-temperature, cool room with air temperature usually of $21^{\circ} \mathrm{C}$. Skin temperature of the toes of $24^{\circ} \mathrm{C}$., or less, was used as the indication of a state of vasoconstriction. Cutaneous vasodilatation was induced by warming the body and by giving food to the subject. Body-warming was accomplished by placing heating pads over the chest and abdomen and covering the subjects with blankets so that only the face, knees, 
TABLE

INTRA-ARTICULAR AND SKIN TEMPERATURES WITH BODY-COOLING AND BODY-WARMING

\begin{tabular}{|c|c|c|c|c|c|c|c|c|c|c|}
\hline \multirow{3}{*}{$\begin{array}{c}\text { Experiment } \\
\text { No. }\end{array}$} & \multirow{2}{*}{\multicolumn{2}{|c|}{$\begin{array}{c}\text { Room Temperature } \\
\left({ }^{\circ} \mathrm{C} .\right)\end{array}$}} & \multirow{2}{*}{\multicolumn{2}{|c|}{$\begin{array}{c}\text { Oral Temperature } \\
\left({ }^{\circ} \mathrm{C} .\right)\end{array}$}} & \multicolumn{4}{|c|}{ Skin Temperature $+\left({ }^{\circ} \mathrm{C}.\right)$} & \multirow{2}{*}{\multicolumn{2}{|c|}{$\begin{array}{l}\text { Intra-Articular } \\
\text { Temperature }\left(^{\circ} \mathrm{C} .\right)\end{array}$}} \\
\hline & & & & & \multicolumn{2}{|c|}{ Knee } & \multicolumn{2}{|c|}{ Toes $\ddagger$} & & \\
\hline & $\mathrm{C}$ & $\mathbf{W}$ & $\mathrm{C}$ & $\mathbf{W}$ & $\mathbf{C}$ & $\mathbf{W}$ & C & $\mathbf{W}$ & $\mathbf{C}$ & $\mathbf{W}$ \\
\hline $\begin{array}{l}1 \\
2 \\
3 \\
4 \\
5 \\
6 \\
7\end{array}$ & $\begin{array}{l}22 \cdot 0 \\
21 \cdot 2 \\
21 \cdot 4 \\
21 \cdot 0 \\
20 \cdot 8 \\
21 \cdot 2 \\
25 \cdot 1\end{array}$ & $\begin{array}{l}21 \cdot 4 \\
21 \cdot 2 \\
21 \cdot 4 \\
20 \cdot 6 \\
20 \cdot 8 \\
21 \cdot 4 \\
25 \cdot 1\end{array}$ & $\begin{array}{l}36 \cdot 8 \\
36 \cdot 7 \\
36 \cdot 7 \\
\overline{36 \cdot 7} \\
36 \cdot 9 \\
37 \cdot 0\end{array}$ & $\begin{array}{c}37 \cdot 2 \\
36 \cdot 3 \\
37 \cdot 0 \\
\overline{37 \cdot 0} \\
37 \cdot 0 \\
36 \cdot 9\end{array}$ & $\begin{array}{l}27 \cdot 6 \\
27 \cdot 2 \\
28 \cdot 0 \\
26 \cdot 2 \\
26 \cdot 8 \\
27 \cdot 0 \\
30 \cdot 2\end{array}$ & $\begin{array}{l}35 \cdot 2 \\
27 \cdot 6 \\
35 \cdot 6 \\
27 \cdot 8 \\
34 \cdot 4 \\
27 \cdot 0 \\
36 \cdot 2\end{array}$ & $\begin{array}{l}21 \cdot 5 \\
21 \cdot 9 \\
21 \cdot 9 \\
22 \cdot 5 \\
21 \cdot 5 \\
21 \cdot 3 \\
24 \cdot 0\end{array}$ & $\begin{array}{l}20 \cdot 9 \\
32 \cdot 2 \\
33 \cdot 5 \\
32 \cdot 6 \\
32 \cdot 5 \\
33 \cdot 8 \\
32 \cdot 5\end{array}$ & $\begin{array}{l}32 \cdot 2 \\
32 \cdot 4 \\
32 \cdot 0 \\
33 \cdot 2 \\
32 \cdot 0 \\
31 \cdot 0 \\
31 \cdot 6\end{array}$ & $\begin{array}{l}37 \cdot 8^{*} \\
31 \cdot 2 \\
37 \cdot 0 \\
35 \cdot 6 \\
38 \cdot 4^{*} \\
30 \cdot 6 \\
38 \cdot 0^{*}\end{array}$ \\
\hline Average ... & & & & & $27 \cdot 6$ & & $22 \cdot 1$ & & $32 \cdot 1$ & \\
\hline
\end{tabular}

$\mathbf{C}=$ While exposed to cool air. $\quad W=$ During body-warming.

$\dagger$ Skin and intra-articular temperatures were taken in the same extremity and the same steady state.

$\ddagger$ Average of at least three toes.

* These three values of the joint temperature bear comment since they are higher than the corresponding orakj temperatures, and the intra-articular temperature of inflamed, arthritic joints (Hollander, Stoner, Brown, and DeMoori 1951). The explanation is probably as follows: Oral temperatures, taken only incidentally in our experiments as a convenient approximation of the "body temperature", are usually less than the rectal temperature (Bard, 1941) and the rectal temperature can be less than the temperature of other parts of the body, including the arterial blood of an extremity (Bazett, Love, Newton, Eisenberg, Day, and Forster, 1948). The arterial blood coming to the kneejoint, in our experiments, was probably still quite warm as blankets covered most of the thigh so that the blood hades to travel only a few inches through that portion of the thigh exposed to cool air. The validity of these three higho joint temperatures is, in a sense, confirmed by the high skin temperatures $\left(34 \cdot 4,35 \cdot 2\right.$, and $36 \cdot 2^{\circ} \mathrm{C}$.) obtained in thesed three experiments, since the deep tissues of an extremity, when surrounded by cool air, must have a temperature 3 higher than that of the skin (Bazett, Love, Newton, Eisenberg, Day, and Forster, 1948).

One very likely explanation for these three joint temperatures being higher than those of arthritic joints is that ${ }^{-}$ the arthritic patients were in a cool room and not body warmed. Our high joint temperatures were obtained ordy $\overrightarrow{0}$ with body warming.

and feet were exposed to the air. Subjects were considered to be in a state of cutaneous vasodilatation when the skin temperature of the toes rose to $30^{\circ} \mathrm{C}$. or higher. In one subject (Experiment 1, Table, Figure, opposite), we were unable to induce vasodilatation of the toes despite prolonged body-heating.

All results are reported for periods when the skin and joint temperatures were stable, toward the end of the period of body-cooling or toward the end of the period of body-warming. Body-cooling averaged about 45 minutes, body-warming about 2 hours.

\section{Results}

(1) With body-cooling, when the toes were in a state of cutaneous vasoconstriction, the intraarticular temperatures were within the narrow range of $31^{\circ}$ to $33 \cdot 2^{\circ} \mathrm{C}$.

(2) With body-warming, when the toes were in a state of cutaneous vasodilatation, the joint temperature increased in four experiments (Nos 3, 4, 5, and 7) to an average of $37 \cdot 3^{\circ} \mathrm{C}$. but did not increase in two experiments ( 2 and 6 ). In a single instance (Experiment 1) the toes remained in a state of cutaneous vasoconstriction while the joint temperature increased to $37 \cdot 8^{\circ} \mathrm{C}$. Thus, in only four of seven experiments did both the intra-articulars temperature and the cutaneous temperature of theō toes increase in response to body-warming.

(3) With body-warming, the intra-articularo changes were much better correlated with the $\overrightarrow{0}$ temperature changes of the skin of the knee. When- 3 ever the joint temperature increased with bodywarming (Experiments 1, 3, 4, 5, and 7), the skin? temperature of the knee also increased, and when-@ ever the joint temperature failed to increase with 0 body-warming, the skin temperature also remained $\frac{\text { O }}{3}$ unchanged (Experiments 2 and 6).

\section{Discussion}

These experiments show that with body-cooling and body-warming no fixed relationship exists between the temperature of the knee joint and the $N$ temperature of the skin of the toes in the same $N$ extremity. The intra-articular temperature of the knees of seven normal subjects varied over the wide ${ }^{\omega}$ range of 31 to $38^{\circ} \mathrm{C}$., with either cutaneous vasoconstriction or vasodilatation in the toes. On the other hand, there is a definite relationship between the intra-articular temperature and the temperature ${ }_{7}^{+}$ 


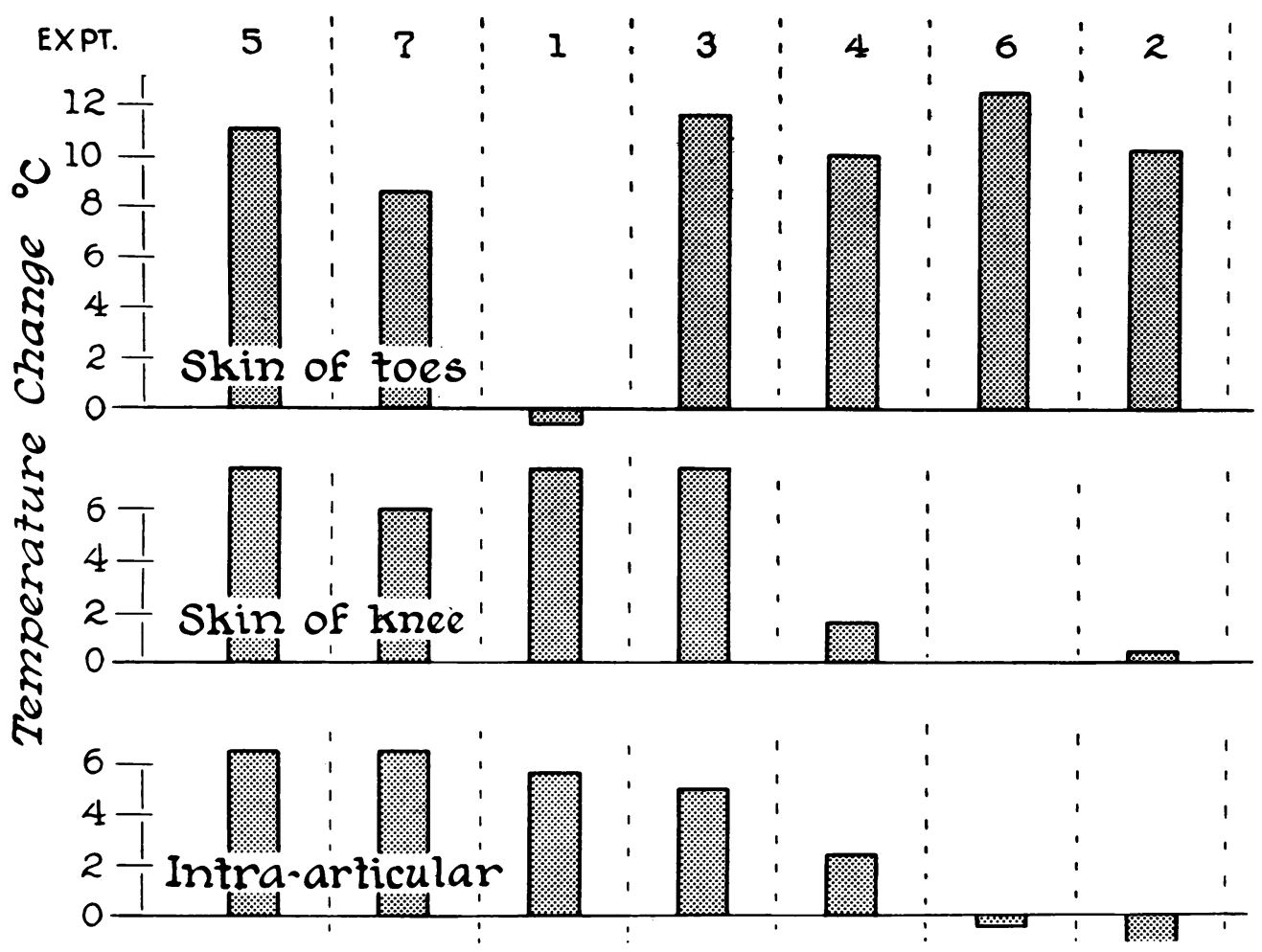

Fig. 1.-Changes in intra-articular and skin temperatures with body-warming.

of the skin directly over the joint. If the temperature of the skin over the joint was lowered to approximately $27^{\circ} \mathrm{C}$. by body-cooling, the joint temperature to between 31 and $33 \cdot 2^{\circ} \mathrm{C}$.; if the skin temperature over the joint was raised to approximately $35^{\circ} \mathrm{C}$. by body-warming, the joint temperature rose to between 37 and $38.4^{\circ} \mathrm{C}$. Thus, the cutaneous temperature of the knee appears to be a reliable index of the intra-articular temperature of the knee joint, in these conditions.

Body-cooling and body-warming affect the temperature of the knee joint differently from the cold packs and hot packs used by Horvath and Hollander (1949). Although our experiments resemble theirs, in that the temperature changes in the knee joint were produced by the application of cold and heat elsewhere to the body, they differ in several important features: the cold and warmth in our experiments were considerably less intense, and were applied to much larger areas and for much longer periods of time. For these and perhaps other reasons the mechanism responsible for changes in joint temperature in our studies is probably different from that responsible for the joint temperature changes noted by Horvath and Hollander. The mechanism in our experiments may well be the same as that producing the skin temperature changes resulting from body-cooling and body-warming. Such skin temperature changes, especially those resulting from bodywarming, have been the subject of many investigations (Gibbon and Landis, 1932; Bazett, 1949; Montgomery, Naide, and Freeman, 1941 ; Richards, 1946; Landis and Gibbon, 1933; Pickering, 1932; McKerslake and Cooper, 1954; Abramson, 1944; DuBois, 1948). Some workers have shown that a considerable time is required after heat is applied before the skin temperature starts to increase, and also that this increase can be prevented by trapping the warmed blood in the area being directly heated. They concluded therefore that such an increase in skin temperature depends largely upon the warming of blood and the arrival of this warmed blood at a "central" terminus (Pickering, 1932; DuBois, 1948; Fulton, 1949; Selle, 1952). The changes in joint temperature resulting from the use of cold and hot packs, on the other hand, came on very quickly after the application of the packs and are attributed 
entirely to a reflex mechanism (Horvath and Hollander, 1949), presumably not depending upon any change in the blood temperature.

If the changes in joint temperature with bodycooling and body-warming in our experiments are due to changes in blood flow to the joint, just as changes in skin temperature are due to changes in blood flow to the skin (Montgomery, Naide, and Freeman, 1941; Richards, 1946), then our observations may have some clinical implications. The relatively low values in joint temperature regularly produced by exposure to cool air would indicate relatively low values of blood flow to the joint, which might account, in part, for the report that exposure to environmental cold and dampness may aggravate certain rheumatic conditions (Holbrook, 1953). The relatively high values of the joint temperature which can be produced by bodywarming would indicate that body-warming is of therapeutic value if, and when, rapid blood flow to the joint is advantageous. Although Bonney, Hughes, and Janus (1952) have shown by plethysmography that body-heating increases blood flow to the knee segment, it is realized that factors other than blood flow to the joint (e.g. a change in the temperature of the blood as it courses through the extremity (see footnote to Table), or a change in blood flow to the skin and soft tissues surrounding the joint) may also have brought about some of the changes in joint temperature observed in our experiments.

\section{Summary}

(1) The intra-articular temperature of the knee of seven normal subjects was measured during a state of cutaneous vasoconstriction of the toes, induced by body-cooling, and then during a state of cutaneous vasodilatation of the toes, induced by body-warming. With cutaneous vasoconstriction from body-cooling, the intra-articular temperature remained within a narrow range $\left(31\right.$ to $33 \cdot 2^{\circ} \mathrm{C}$.), but with vasodilatation the joint temperature varied considerably $\left(30.6\right.$ to $38 \cdot 4^{\circ} \mathrm{C}$.).

(2) The skin temperature of the knee was also measured and was found to have a better correlation with the joint temperature; when the skin temperature was lowered to approximately $27^{\circ} \mathrm{C}$. by bodycooling, the joint temperature fell to between 31 and $33 \cdot 2^{\circ} \mathrm{C}$, , and when the skin temperature was raised to approximately $35^{\circ} \mathrm{C}$. by body-warming, the joint temperature rose to between 37.0 and $38 \cdot 4^{\circ} \mathrm{C}$.

(3) The response of the joint temperature to the application of cold or heat to another part of the body depends apparently on the intensity, location, and duration of the temperature stimulus, since body-cooling and body-warming affect the temperature of a knee joint differently from the cold packs and hot packs applied to the contralateral knee by Horvath and Hollander (1949).

(4) Some speculations are made on the effect of $\stackrel{\vec{F}}{\stackrel{\vec{P}}{+}}$ body-cooling and body-warming upon blood flow to the joint and upon rheumatic disease.

\section{REFERENCES}

Abramson, D. I. (1944). "Vascular Responses in the Extremities of Man in Health and Disease", p. 98. University of Chicago $\backsim$

Bard, P. (1941). In “Macleod's Physiology in Modern Medicine", ed. P. Bard, 9th ed., p. 862. Mosby, St. Louis.

Bazett, H. C. (1949). In "Physiology of Heat Regulation and the $\vec{\omega}$ Science of Clothing", ed. L. H. Newburgh, pp. 163-168.

—, Love, L., Newton, M., Eisenberg, L., Day, R., and Forster, R., II (1948). J. appl. Physiol., 1, 3.

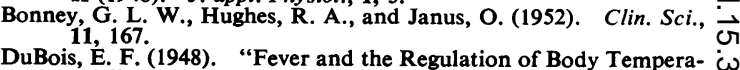

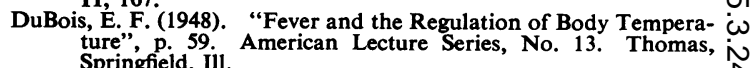
ture”, p. 59. American Lecture Series, No. 13. Thomas, i

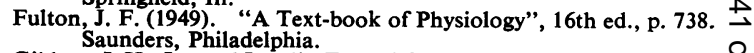
Gibbon, J. H., Jr., and Landis, E. M. (1932). J. clin. Invest., 11, 1019. 음 Holbrook, W. P. (1953). In "Comroe's Arthritis", 5th ed., ed. J. L. 工 Hollander, pp. 517-521. Lea and Febiger, Philadelphia. Hollander, J. L., and Horvath, S. M. (1949). Amer. J. med. Sci., $\mathbb{D}$
218, 543. 218, Stoner, E. K., Brown, E. M., Jr., and DeMoor, P. (1951). J.
clin. Invest., 30, 701.

Horvath, S. M., and Hollander, J. L. (1949). Ibid., 28, 469.

Landis, E. M., and Gibbon, J. H., Jr. (1933). Arch. intern. Med., 52,785 .

McKerslake, D. McK., and Cooper, K. E. (1954). In "Periphera Circulation in Man", ed. G. E. W. Wolstenholme and J. है $\vec{c}$ Freeman, p. 115. Ciba Foundation Symposium. Churchip of London.

Montgomery, H., Naide, M., and Freeman, N. E. (1941). Ameל̋

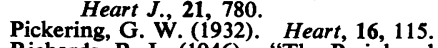

Richards, R. L. (1946). "The Peripheral Circulation in Health and Disease", pp. 42-46. Livingstone, Edinburgh.

Selle, W. A. (1952). "Body Temperature. Its Changes with Environment, Disease, and Therapy", pp. 38-46. American Lecture Series, No. 147. Thomas, Springfield, Ill.

La température intra-articulaire du genou au cours de la vasoconstriction et vasodilatation cutanées des orteils chez des sujets normaux

RÉSUMÉ

(1) La température intra-articulaire du genou de sept sujets normaux fut mesurée pendant un état de vaso- 을 constriction cutánée des orteils produit par refroidissement du corps, puis pendant un état de vasodilatation $\Xi$ cutánée des orteils produit par réchauffement du corps. Avec la vasoconstriction cutanée par refroidissement du corps, la température intra-articulaire demeurait dans des limites étroites $\left(31^{\circ}\right.$ à $\left.33^{\circ} 2\right)$, mais avec la vasodilatation, la température articulaire variait considérablement $\left(30^{\circ} 6\right.$ a $\left.38^{\circ} 4\right)$.

(2) La température de la peau du genou fut aussi mesurée et révéla une meilleure corrélation avec la $\mathrm{N}$ température articulaire; quand la température cutanée $\sigma$ fut abaissée à environ $27^{\circ}$ par refroidissement du corps, N l'articulaire tomba entre $31^{\circ}$ et $33^{\circ} 2$, et quand la cutanée fut élevée à environ $35^{\circ}$ par rechauffement du corps, l'articulaire s'éleva entre $37^{\circ}$ et $38^{\circ} 4$.

(3) La réponse de la température articulaire à l'application de froid ou de chaud à une autre région du corps depend apparemment de l'intensité, de la location et de la durée du stimulus calorique, puisque le refroidissement et le réchauffement du corps affectent 
la température d'une articulation du genou d'une manière différente que l'application d'enveloppements froids ou chauds au genou contralatéral, procédé appliqué par Horvath et Hollander (1949).

(4) Quelques spéculations sont faites sur les effets du refroidissement et du réchauffement du corps sur l'irrigation sanguine du genou et sur la maladie rhumatismale.

\section{La temperatura intra-articular de la rodilla en el curso de la vasoconstricción $y$ vasodilatación cutáneas de los dedos del pie en sujetos sanos}

\section{Sumario}

(1) Se midió en siete sujetos normales la temperatura intra-articular de la rodilla durante un estado de vasoconstricción cutánea de los dedos del pie producida al resfriar el cuerpo, y luego durante un estado de vasodilatación cutánea de los dedos del pie producida al calentar el cuerpo. Con la vasoconstricción cutánea por el resfriamiento del cuerpo, la temperatura intraarticular quedaba dentro de límites estrechos $\left(31^{\circ} \mathrm{a}\right.$ $33^{\circ} 2$ ), pero con la vasodilatación ésta varíaba considerablemente $\left(30^{\circ} 6\right.$ a $\left.38^{\circ} 4\right)$.

(2) Se midío también la temperatura de la piel de la rodilla, revelando una mejor correlación con la temperatura articular; al bajar la temperatura cutànea a cerca de $27^{\circ}$ por un resfriamiento del cuerpo, la de la articulación cayó entre $31^{\circ}$ y $33^{\circ} 2$ y al subirla a cerca de $35^{\circ}$ por un calentamiento del cuerpo, la temperatura articular alcanzó $37^{\circ}$ a $38^{\circ} 4$.

(3) La respuesta de la temperatura articular a la aplicación del frío o del calor a otra parte del cuerpo depende aparentemente de la intensidad, del sitio y de la duración del estímulo calórico, ya que el resfriamiento y el calentamiento del cuerpo afectan la temperatura de una articulación de la rodilla de una manera diferente que la aplicación de envolturas frías o calientes a la rodilla contralateral, procedimiento empleado por Horvath y Hollander (1949).

(4) Se discuten algunas ideas acerca de los efectos del resfriamiento y del calentamiento del cuerpo sobre el riego sanguíneo de la rodilla y sobre la enfermedad reumática. 